\title{
LENDS: An Approach to the Centralization/Decentralization Dilemma
}

\begin{abstract}
Traditionally academic librarians have been subjected to pressure from faculty to provide decentralized (divisional and departmental) libraries. Faculty at Georgia Tech have been provided with remote bibliographic access to the Georgia Tech Library through microfiche copies of the card catalog. Remote physical access is provided through a delivery service. This system (called LENDS) permits decentralized service to faculty from a centralized library. Faculty acceptance and use of LENDS are examined in this paper.
\end{abstract}

A

RECENT ARTICLE by Waldhart and Zweifel on the organizational patterns of scientific and technical libraries surveys the longstanding dilemma of centralized versus decentralized library organization. ${ }^{1}$ Generally speaking, librarians have favored a centralized organization, and faculty have argued for decentralized libraries (often down to the departmental level). One trend is to compromise and organize scientific and technical libraries around a number of related academic fields (e.g., life science).

The arguments against decentralized libraries listed by Waldhart and Zweifel

Robert J. Greene is librarian, Kennesaw Junior College, Marietta, Georgia. The author gratefully acknowledges the aid of Graham Roberts, Arthur Kittle, Ann Bugg, and Helen Citron of the Georgia Tech library staff in the preparation of this article. are that decentralization "(1) generates numerous problems of communication, control, and coordination; (2) results in rising cost through the duplication of library services, materials, personnel, and records; and (3) encourages, whenever materials are not duplicated, the fragmentation of knowledge and isolation of scientific and technical fields." Faculty members, however, contend that: "their work (primarily their research activities) requires unlimited access to library materials over time, and in addition that library materials should be physically situated in close proximity to the greatest number of potential users." 2

The problem of providing better access to an almost wholly centralized library collection and services had received considerable attention at Georgia Institute of Technology. A rapidly expanding campus plus limited parking near the library had made library use in- 
convenient for some faculty. A system called LENDS (Library Extends Cata$\log$ Access and New Delivery Service) was developed. LENDS provides faculty with the option of receiving library service while remaining in their departments.

Remote bibliographic access is provided through the distribution of microfiche copies of the card catalog to thirty-five academic and research departments. Each catalog installation is supplied with a $50 \times$ magnification microfiche reader. The microfiche catalog is in two parts: a basic file created by filming the card catalog and a bimonthly computer output microfilm (COM) supplement. The basic file, consisting of 717 fiche, contains nearly 800,000 entries. The COM supplement is a cumulative listing of all entries added to the catalog since September 1971. A detailed account of the development and implementation of the LENDS microfiche catalog has been published by Roberts and Kennedy. ${ }^{3}$

Books, copies of journal articles, technical reports, and other library material may be requested by telephone. Items are delivered on morning and afternoon schedules to all departments. Deliveries are made in a battery-operated cart owned by the library. Items borrowed from the library may be returned through the delivery service.

\section{DESCRIPTION OF LENDS STUdIES}

Faculty acceptance and use of LENDS was studied by Greene. ${ }^{4}$ Three methods were used to obtain data for this investigation: (1) an analysis of faculty library book circulation statistics for periods before and after the start of LENDS; (2) questionnaires sent to faculty who had borrowed library books before and after the start of LENDS; and (3) interviews with faculty who had used LENDS and faculty who continued to obtain library books in the conventional way.

\section{Study of Circulation Statistics}

Circulation statistics for periods before and after the start of LENDS were analyzed to determine if the availability of LENDS was related to an increase in library books circulated to faculty. The spring quarter 1971 and the spring quarter 1972 were selected as sampling periods. The two sampling periods were compared for number of students enrolled, number of faculty and staff employed, number of active research projects, and other factors which might affect the number of library books circulated. The two quarters were found to be similar in all respects. The only change in circulation policy or circulation procedure between the two quarters was the implementation of LENDS.

It was assumed that LENDS would improve faculty access to the book collection of the Georgia Tech Library. A study by Harris suggests that if improved access is provided to a library collection, greater use will be made of that collection. ${ }^{5}$ Therefore, if LENDS did improve faculty access to the book collection, greater faculty use of the collection should be noted. Table 1 shows the data collected to test this hypothesis.

\section{TABLE 1}

Circulation Statistics for Spring 1971 AND SPRING 1972

\begin{tabular}{|c|c|c|c|}
\hline Type of Circulation & $\begin{array}{c}\text { Spring } \\
1971 \\
\text { Number } \\
\text { of Books }\end{array}$ & $\begin{array}{c}\text { Spring } \\
1972 \\
\text { Number } \\
\text { of Books }\end{array}$ & $\begin{array}{l}\text { Percent } \\
\text { Change }\end{array}$ \\
\hline Student Circulation & 19,904 & 19,992 & +0.44 \\
\hline $\begin{array}{l}\text { Other Circulation } \\
\text { Faculty Circulation }\end{array}$ & & 889 & \\
\hline (Regular) & 3,122 & 3,363 & +7.76 \\
\hline $\begin{array}{l}\text { Faculty Circulation } \\
\text { (LENDS) }\end{array}$ & 0 & 521 & - \\
\hline $\begin{array}{l}\text { Total Book } \\
\text { Circulation }\end{array}$ & 23,997 & 24,765 & +3.21 \\
\hline
\end{tabular}

- Other circulation includes off-campus and special borrowers. 
TABLE 2

How Faculty Obtained Books in the Pre-LENDS and Post-LendS Samples

\begin{tabular}{|c|c|c|c|c|}
\hline \multirow[b]{2}{*}{ How Books Were Obtained } & \multicolumn{2}{|c|}{$\begin{array}{l}\text { Pre-LENDS Sample } \\
\text { of Books }\end{array}$} & \multicolumn{2}{|c|}{$\begin{array}{l}\text { Post-LENDS Sample } \\
\text { of Books }\end{array}$} \\
\hline & Number & Percent & Number & Percent \\
\hline 1. By telephoning the request to the library & 0 & 0.0 & 48 & 21.6 \\
\hline 2. By going to the library & 184 & 88.0 & 159 & 71.6 \\
\hline 3. By sending someone to the library & 22 & 10.5 & 6 & 2.7 \\
\hline 4. Some other way ${ }^{\circ}$ & 1 & 0.5 & 4 & 1.8 \\
\hline 5. No response & 2 & 1.0 & 5 & 2.3 \\
\hline Total & 209 & 100.0 & 222 & 100.0 \\
\hline
\end{tabular}

- The only faculty who chose this answer were librarians who were already in the library and, therefore, did not "go to the library."

The following proportions indicate that faculty circulation was a greater part of the total circulation after the start of LENDS:

\section{Before LENDS}

Faculty Book Circulation,

$\frac{\text { Spring Quarter } 1971}{\text { Total Book Circulation, }}=\frac{3,122}{23,997}=.13$ Spring Quarter 1971

\section{After LENDS}

Faculty Book Circulation,

Spring Quarter 1972

Total Book Circulation, $=\frac{3,884}{24,765}=.16$

Spring Quarter 1972

The difference between these two proportions was found to be statistically significant. It was concluded that the increase in faculty book circulation was probably related to the presence of LENDS.

It is also suggested that LENDS may be responsible for some increase in conventional book circulation. It can be noted from Table 1 that regular (nonLENDS) faculty circulation increased by 7.76 percent. There is reason to suspect, although none of these books were checked out through LENDS, that the increase was due to the availability of the LENDS microfiche catalogs in the various departments. Some faculty interviewed indicated that they had used LENDS catalogs but had gone to the library to obtain the books rather than using the LENDS delivery system.

\section{Circulation Questionnaire}

The faculty book circulation file was randomly sampled before the start of LENDS (November 1971) and after the start of LENDS (May 1972). A questionnaire was sent to the faculty member responsible for each of the sampled book charges. Of the 233 preLENDS questionnaires sent out, 209 ( 89.7 percent) were returned; and out of the 244 post-LENDS questionnaires sent out, 222 (91.0 percent) were returned.

In both the pre-LENDS and the postLENDS questionnaires faculty were asked: "How did you obtain this book?" The distribution of the replies to this question is shown in Table 2.

It can be seen that LENDS had an effect on the three main ways in which faculty obtain library books: (1) telephone requests increased from 0 to 21.6 percent; (2) books obtained by going to the library decreased by 16.4 percent; and (3) books obtained by sending someone to the library decreased by 7.8 percent. From these data it was concluded that LENDS did affect the ways in which faculty obtain books. The most obvious change was the substitution of the telephone and book delivery for faculty trips to the library.

Faculty were asked the question, "Who within the library retrieved the book from the shelves?" Table 3 sum- 
TABLE 3

Who within the Library Retrieved the Books in the Pre-LENDS and Post-LENDS SAMpLes

\begin{tabular}{|c|c|c|c|c|}
\hline \multirow{2}{*}{$\begin{array}{l}\text { Who Retrieved the Book } \\
\text { from the Bookstacks }\end{array}$} & \multicolumn{2}{|c|}{$\begin{array}{l}\text { Pre-LENDS Sample } \\
\text { of Books }\end{array}$} & \multicolumn{2}{|c|}{$\begin{array}{c}\text { Post-LENDS Sample } \\
\text { of Books }\end{array}$} \\
\hline & Number & Percent & Number & Percent \\
\hline 1. Member of library staff & 8 & 3.8 & 57 & 25.7 \\
\hline 2. Faculty member and library staff & 6 & 2.9 & 2 & 1.0 \\
\hline 3. Faculty member only & 172 & 82.3 & $15 \overline{4}$ & 69.3 \\
\hline 4. Someone else & 20 & 9.6 & 6 & 2.7 \\
\hline 5. No response & 3 & 1.4 & 3 & 1.3 \\
\hline Total & 209 & 100.0 & 222 & 100.0 \\
\hline
\end{tabular}

marizes faculty replies to this question.

It can be seen from the data in Table 3 that, after LENDS, the library staff assumed a greater portion of the responsibility for retrieval of books from the shelves. Some indication of the overall cost saving potential of LENDS is also shown in the preceding two tables. These data show that relatively inexpensive student assistant and clerical time is substituted for expensive faculty time in retrieval of books from the library shelves and delivery of books to faculty work areas.

\section{Faculty Interviews}

Fifty faculty who had borrowed books through LENDS and fifty faculty who continued to borrow books in the conventional manner were interviewed. These LENDS users and LENDS nonusers were classified into four zones according to the distance of their offices from the library. This classification was made to test for a possible relationship between the distance of a faculty member's office from the library and his use of LENDS. Table 4 shows that faculty located farthest from the library (Zone III and IV) were more likely to be LENDS users. Chi-square analysis of these data indicates that this relationship is statistically significant.

The fifty LENDS non-users were asked why they had not used LENDS to borrow books instead of going to the library. Table 5 summarizes the replies to this question.

Several observations can be made from Table 5. First, the rather nebulous reason of "inertia" was uncovered as an important factor in the non-use of LENDS. If the sample of LENDS nonusers can be taken as representative of the whole population of non-users, then 27 percent of the LENDS non-users have rather indefinite reasons for continuing to go to the library. Second, a

TABLE 4

Distance of Faculty Member's Office from Library and Use of LENDS

\begin{tabular}{|c|c|c|c|c|c|}
\hline $\begin{array}{l}\text { Use of } \\
\text { LENDS }\end{array}$ & $\begin{array}{l}\text { Number of } \\
\text { Faculty with } \\
\text { Offices in } \\
\text { Zone I }\end{array}$ & $\begin{array}{c}\text { Distance of Faculty } \\
\text { Number of } \\
\text { Faculty with } \\
\text { Offices in } \\
\text { Zone II }\end{array}$ & $\begin{array}{l}\text { Office from Library } \\
\text { Number of } \\
\text { Faculty with } \\
\text { Offices in } \\
\text { Zone III }\end{array}$ & $\begin{array}{l}\text { Number of } \\
\text { Faculty with } \\
\text { Offices in } \\
\text { Zone IV }\end{array}$ & Total \\
\hline Users & 7 & 7 & 18 & 18 & 50 \\
\hline Non-Users & 21 & 8 & 13 & 8 & 50 \\
\hline Total & 28 & 15 & 31 & 26 & 100 \\
\hline
\end{tabular}

$\mathrm{X}^{2}=11.72, d f=3$, significant at .01 level 
TABLE 5

Reasons Given by a SAMPLE OF LENDS NON-UsERS For Not UsING LENDS

\begin{tabular}{|c|c|}
\hline Reason & $\begin{array}{c}\text { Number } \\
\text { Citing }\end{array}$ \\
\hline $\begin{array}{l}\text { 1. Inertia (e.g., "I have not gotten around } \\
\text { to it," or "I will try it sometime") } \\
\text { 2. I like to go to the library } \\
\text { 3. I have not had occasion to use LENDS } \\
\text { (note: all faculty classified as non-users } \\
\text { had borrowed at least one book from } \\
\text { the library during May 1972) } \\
\text { 4. It is more convenient for me to go to } \\
\text { the library } \\
\text { 5. I like to browse or look at the books I } \\
\text { select } \\
\text { 6. I do not fully understand LENDS } \\
\text { (note: all persons interviewed had } \\
\text { heard or read about LENDS) }\end{array}$ & i \\
\hline
\end{tabular}

Note: Some persons interviewed gave more than one reason for not having used LENDS.

large proportion of the LENDS nonusers like to go to the library and like to browse. Some critics of remote access systems may justifiably raise the point that persons who like to use the library and who like to browse should not be encouraged to use a system which will deprive them of this pleasure.

Reason three ("I have not had occasion to use LENDS") may be questioned since all persons selected as LENDS non-users had borrowed at least one library book during May 1972; they all had the opportunity to use LENDS. It may be that some of these faculty just did not think about LENDS when the necessity of borrowing a book arose. This, together with reason six ("I do not fully understand LENDS"), suggests that some LENDS non-users might become LENDS users if exposed to an intensive and personalized education program about LENDS.

Little can be done to convert the LENDS non-users who gave reason number four (“. . . more convenient for me to go to the library") for not using LENDS. For the most part, these faculty members had offices in buildings adjacent to the library, and it may well be
TABLE 6

Problems LENDS Users ENCOUNTEREd IN UsING LENDS

\begin{tabular}{lr}
\hline \hline \multicolumn{1}{c}{ Problem } & $\begin{array}{r}\text { Number } \\
\text { Citing }\end{array}$ \\
\hline 1. Finding the correct microfiche from \\
the author/title, subject, or serials \\
files
\end{tabular}

Note: Several interviewees checked more than one problem, and sixteen interviewees did not check any.

easier and quicker for them to go to the book rather than wait for the book to be brought to them.

The fifty LENDS users interviewed were asked to indicate what problems (if any) they had in using LENDS. Table 6 shows their replies.

It should be noted that very few faculty mentioned any difficulties in using LENDS after their first try. The high number of faculty who checked reason number five is attributed to the nonobvious location of the focus control on the reader used. Of course, those who cited reason number eight would have also been disappointed if they had gone to the library for the book.

The fifty LENDS users were also asked to cite any advantage they saw in using LENDS instead of the conven- 
tional method of obtaining books. Their replies are summarized in Table 7.

\section{TABLE 7}

Advantages of LENDS as Stated by a SAMPLE OF FIFTY LENDS UsERS

\begin{tabular}{|c|c|}
\hline Advantages of LENDS & $\begin{array}{l}\text { Number } \\
\text { Citing }\end{array}$ \\
\hline $\begin{array}{l}\text { 1. Overall convenience of LENDS } \\
\text { 2. LENDS is faster than conventional } \\
\text { way of obtaining library books } \\
\text { 3. Does not require walking to the li- } \\
\text { brary } \\
\text { 4. The LENDS catalog provides a } \\
\text { knowledge of the library collection } \\
\text { without leaving my department } \\
\text { 5. Saves trying to locate a parking space } \\
\text { at the library } \\
\text { 6. It is easier to browse or scan the } \\
\text { microfiche catalog than the card } \\
\text { catalog } \\
\text { 7. Books (entries) are easier to locate } \\
\text { in the microfiche catalog } \\
\text { 8. I do not have to wander around the } \\
\text { library to locate a book } \\
\text { 9. I can sit down while using the micro- } \\
\text { fiche catalog } \\
\text { 10. A report on the status of books not } \\
\text { received (e.g., lost or on reserve) } \\
\text { is provided as a part of the system } \\
\text { 11. I do not have to carry large numbers } \\
\text { of books back to my office } \\
\text { 12. I tend to return books to the library } \\
\text { as soon as I am finished with them } \\
\text { instead of waiting until my next trip } \\
\text { to the library } \\
\text { 13. My office has become equivalent to a } \\
\text { carrel in the library } \\
\text { 14. By using the microfiche catalog, I } \\
\text { can make students aware of library } \\
\text { materials }\end{array}$ & tos \\
\hline
\end{tabular}

Note: Several LENDS users cited more than one advantage.

\section{LENDS TODAY}

The information about LENDS for this investigation was gathered during the first full academic quarter of its operation in the spring of 1972. Since this time, LENDS services have been expanded in the following ways:

1. Computerized literature searches are offered through the Reference Department and the University of Georgia's Information Dissemination Center.
2. Many academic departments combine LENDS with appropriate abstracting or indexing services for remote access to journal and report literature. Photocopies of requested articles are delivered through LENDS.

3. Three LENDS microfiche catalogs (and readers) have been made available for home or classroom use.

4. LENDS pick-up stations are now in dormitories, the student center, and other buildings for convenient return of library materials loaned to students.

5. The LENDS microfiche catalog has been purchased by other libraries (one in Hong Kong), and remote physical access is provided through interlibrary loan and photocopy service.

6. LENDS microfiche catalogs and intercom telephones have been placed at several locations within the Georgia Tech Library. Library users may obtain catalog aid and information concerning the location of materials from the Circulation Department.

7. Several graduate students are using LENDS services.

LENDS use has grown dramatically over the past two years. Over 6,600 items (books, photocopies, literature searches) were delivered to faculty through LENDS in the 1972-73 fiscal year. The number of items delivered during the 1973-74 fiscal year mushroomed to nearly 25,000. The Georgia Tech School of Computer and Information Science and the library staff are continuing the evaluation of LENDS under a National Science Foundation grant.

\section{SUMMARY}

The LENDS remote access system has allowed the Georgia Tech Library to decentralize services in an essentially 
centralized library. Faculty have access to library materials without leaving their departments. Remote bibliographic and physical access has made it easier for many faculty to obtain books, and, therefore, the faculty circulation of books has increased. LENDS is used most heavily by faculty situated farther from the library.

Several Georgia Tech faculty have yet to give LENDS a try. Some faculty continue to come to the library out of habit or preference, and some faculty, situated near the library, feel that going to the library is still more convenient. Acceptance of LENDS by those faculty who have tried it has been gratifying. Since more of the responsibility of getting books to the faculty has been as- sumed by the library staff, these faculty can spend this time on more productive tasks. LENDS users have adapted to the new system with very few problems and, in general, are strong supporters of the system.

LENDS, described most simply, sends library materials and services to users instead of requiring users to come to the library. As LENDS services are expanded, and as faculty acceptance of LENDS grows, the implications of this nontraditional approach to library organization will become increasingly important. Not the least of these implications aims at a possible solution to the centralization/decentralization dilemma.

\section{REFERENCES}

1. Thomas J. Waldhart and Leroy G. Zweifel, "Organizational Patterns of Scientific and Technical Libraries: An Examination of Three Issues," College \& Research Libraries 34:427-35 (Nov. 1973).

2. Ibid., p.427.

3. Edward Graham Roberts and John P. Kennedy, "The Georgia Tech Library's Microfiche Catalog," Journal of Micrographics 6: 245-51 (July 1973).
4. Robert John Greene, "Faculty Acceptance and Use of a System Providing Remote Bibliographic and Physical Access to an Academic Library" (Ph.D. dissertation, Florida State Univ., 1973).

5. Ira Whitney Harris, "The Influence of Accessibility on Academic Library Use" (Ph.D. dissertation, Rutgers, The State University, 1966). 